\title{
The US and NATO Expansion: Fulfilling a Domestic Political Agenda
}

\author{
Luca Ranise* \\ *CLEPUL - Centro de Literaturas e Cultura Lusófonas e Europeias, Portugal; desmoluca69@hotmail.com
}

\begin{abstract}
Resumo
A expansão da NATO tem sido, certamente, um tema bastante controverso que continua a dividir o mundo em apoiantes e oponentes. Várias razões têm sido apresentadas para justificar a decisão de alargamento da NATO, nomeadamente a securitização e estabilização da Europa, a democratização dos países anteriormente sob a alçada soviética ou o reforço da eficácia e coesão da Aliança. Embora todas essas propostas possam ser válidas, este artigo quer analisar se, como tem sido afirmado por diversos intervenientes, a decisão dos EUA de ampliar a NATO, respondeu em primeiro lugar, às considerações de realpolitik. Quer-se investigar, se é verdade que o alargamento abordou preocupações de política doméstica específica dos EUA, que tiveram a sua expressão também em iniciativas de política externa e, mais especificamente, se o presidente Clinton usou o alargamento da NATO para aumentar as suas probabilidades de reeleição. $\mathrm{O}$ estudo realizado demonstra que foi realmente assim e que, o presidente Clinton não poderia ter seguido uma política diferente. Sem o compromisso firme dos EUA de expandir a NATO, o alargamento da Aliança provavelmente nunca teria ocorrido.
\end{abstract}

Palavras-chave: Expansão da NATO, Neorrealismo, Opção Racional, Realpolitik

\begin{abstract}
The expansion of NATO has certainly been a very controversial issue that still sees the world divided into supporters and opponents. Various reasons have been brought forward to justify why the NATO enlargement decision was taken, inter alia the securitisation and stabilisation of Europe, the democratisation of the countries formerly under the Soviet yoke or the enhancement of the Alliance's effectiveness and cohesion. Although all such propositions might be valid, this article wants to analyse if indeed, as often claimed, the US decision to enlarge NATO responded first and foremost to realpolitik considerations, and namely if it is true that enlargement addressed specific US's domestic political concerns that had their expression also in foreign policy initiatives, and more specifically if President Clinton used NATO enlargement to enhance his chances of re-election. The study conducted demonstrates that it was indeed so and that President Clinton could have not possibly followed a different policy. Without the firm US commitment to expand NATO, the enlargement of the Alliance would have probably never taken place.
\end{abstract}




\section{Introduction}

There are many reasons that can possibly explain the NATO enlargement policy, to include the securitisation and stabilisation of Europe, the democratisation of the countries formerly under the Soviet yoke or the enhancement of the Alliance's effectiveness and cohesion. Without discarding the validity of such propositions, this paper defends that the US decision to enlarge NATO, that is to admit new members into the Alliance, responded first and foremost to specific US's domestic political concerns that had their expression also in foreign policy initiatives, and namely that President Clinton used enlargement to enhance his chances of re-election. It is argued that the decision to expand NATO was a realpolitik choice, as not following such policy would have had clear political costs. Had there not been a clear domestic political advantage for the then US President, given the international political context enlargement would have probably not taken place.

Although such conclusions are not new, the existing literature has analysed this proposition in a fragmented manner. This article tries to fill this gap by providing a longitudinal study that exhaustively addresses the phenomenon at large, and provides unquestionable evidence that indeed President Clinton used enlargement for political returns. In methodological terms, a comprehensive review of the literature on NATO enlargement was conducted, to include over 350 journal articles, books and other publications on the subject, and text analysis performed using text analysis software and its embedded coding system.

NATO expansion has certainly been a very controversial issue that still sees the world divided into supporters and opponents. On the one side, the legislative and executive branches of the US government, as well as the bureaucracy, were all against enlargement, and the future of NATO in general triggered little interest within the Congress (see for example Goldgeier, 1999).

Similarly, the academic literature was at odds with the decision to enlarge, and there was bipartisan agreement on the fact that enlarging the Alliance was a bad decision (see for example Gaddis, 1998).

On the other side, the enlargement policy was instead supported by key personalities of the Clinton administration such as National Security Adviser Anthony Lake, Deputy Secretary of State Strobe Talbott and Assistant Secretary of State Richard Holbrooke $^{[1]}$. As known, the latter side prevailed and against all initial expectations on 30 April 1998 the US Senate approved the expansion of NATO by vote of 80 to 19. How was this possible? What pushed president Clinton to support this policy and why the US Senate approved it?

This article tries to respond to these and other questions and is structured into two main parts. The first provides a succinct overview of the enlargement phenomenon, whereas the second explains the reasons why an initially reluctant President Clinton decided to espouse the NATO enlargement policy.

1. See for example Goldgeier (1998). 


\section{The NATO Enlargement Debate}

As suggested, the debate on NATO enlargement was and still is characterised by sharp divisions between supporters and opponents. The debate that preceded the first enlargement round of the Alliance, which took place in 1999 and which set the basis for the subsequent extension of NATO membership to our days, spanned from the position of those who wanted a fast track to enlargement to those who refused enlargement altogether.

The first mainly argued that enlargement was needed for the security of Europe as a whole, as CEE countries were seen as inherently instable and prone to create tensions that could have in turn ended up into new Bosnia-like conflicts. Rejecting enlargement could have also led to renationalisation of defence policies or a proliferation of security agreements, scenarios that had to be avoided. For example, Mandelbaum (1995) recalled that "proponents of expansion assert that a security vacuum in Europe must be filled by 'new security architecture', of which a NATO encompassing central Europe ought to be an important part" (p. 12). However, even supporters of enlargement recognised that the rationale for expansion did not exist even after the policy had been announced (see for example Goldgeier, 1999 or Holbrooke, 1995) ${ }^{[2]}$.

The second considered such policy riddled with logical inconsistencies (Kupchan, 2001), were contesting the vision of CEE as instable countries and rejected enlargement on the grounds that there were no threats in Europe that could justify it. On the contrary, they warned on the fact that enlarging the Alliance would have alienated Russia and so created the threat everyone wanted to avoid, and defended alternatives to NATO expansion such as neutrality for the new democracies or their maintenance in the Partnership for Peace programme. An important testimony of such lack of support for a potential NATO enlargement could be found in a recently declassified document of the US Department of State dating back 1990, which indicated that:

In the current environment, it is not in the best interest of NATO or the US that these states be granted full NATO membership and its security guarantees. We are not in a position to guarantee the security of these countries vis-à-vis the Soviets, and do not in any case wish to organize an anti-Soviet coalition whose frontier is the Soviet border. Such a coalition would be perceived very negatively by the Soviets and could lead to a reversal of current positive trends in Eastern Europe and the USSR (Dobbins, 1990, p. 4).

Other eminent personalities adversed NATO enlargement, to include George Kennan, who defended that expanding NATO would be the most fateful error of American policy in the entire post-Cold War era and remembered that justifying

2. Interestingly, Goldgeier (1999) comments that "normally, one might expect the rationale for a policy to be worked out before its announcement. And had this policy evolved along a formal decision path, that might have been the case. But it had not. No one seemed to have any hesitation to deliver speeches in 1994 and 1995 talking about the need to develop a rationale for a policy they claimed the president had enunciated in January 1994" (p. 94). 
NATO expansion on the view of Russia "as an inherently and incorrigibly expansionist country... grossly oversimplifies and misconstrues most of the history of Russian diplomacy of the czarist period [and] ignores the whole great complexity of Russia's part in World War II" (Kennan, 1998, p. S1284). Others stressed that "there is no Russian national equivalent of a genetic predisposition to aggression [and therefore] expansion is not only unwise but unnecessary" (Mandelbaum, 1995, pp. 11-12), or that "isolation and confrontation by an expanding military alliance are not the way to create a friend and ally" (Carrol, 1998). Finally, those at the far end of the spectrum were even advocating the suppression of NATO and the implementation of new pan-European security arrangements that would embrace all former communist states, to include Russia.

In substance, enlargement was in turn labelled "logical and essential" (Holbrooke, 1995, p. 42) on the one side or an "act of folly" (T. L. Friedman, 1998), a "epic fateful error" (Carrol, 1997) or a "policy error of historic importance" (Mccgwire, 2008) on the other. The same Mcgwire (2008) also argued that the right to join an alliance could not be considered in isolation of other international principles, such as the need to balance this right with the obligation not to strengthen one party's security at the expense of another's, an obligation that applies equally to alliances, as indicated in the OSCE Code of Conduct on Politico-Military Aspects of Security ${ }^{[3]}$.

Within the academic literature, as previously hinted, realists announced that with the end of the Cold War and the collapse of its historical enemy, NATO would soon disappear as "alliances have no meaning apart from the adversary threat to which they are a response" (Snyder, 1997, p. 192), and at least initially the desire to cash the 'peace dividend', which entailed drastic reduction in military forces (to include the end of conscription) and defence budgets across all major NATO nations seemed to indeed point in that direction. Realists' predictions proved however erroneous as we all know, and in line with neorealist theory NATO has survived as a means to maintain US grip on Europe, "as the instrument for maintaining America's domination of the foreign and military policies of European states" (Waltz, 2000b, p. 21). Indeed, NATO has always been and remains an instrument of US's foreign policy, for example by providing "putative legal legitimacy to operations that cannot achieve UN endorsement due tue Russian or Chinese opposition in the Security Council" (Hallams, Ratti, \& Zyla, 2013, p. 13) or by granting access to European infrastructure and facilities for operations outside Europe, to the extent that we have assisted to a "high level of tolerance on the part of the United States for a commitment to NATO even in the face of decades of exposure to free-riding behaviour" (Webber, 2013, p. 32).

3. Article I.3 of the OSCE Code of Conduct on Politico-Military Aspects of Security (OSCE, 1994) establishes that the participating states "remain convinced that security is indivisible and that the security of each of them is inseparably linked to the security of all others. They will not strengthen their security at the expense of the security of other States. They will pursue their own security interests in conformity with the common effort to strengthen security and stability in the CSCE area and beyond". 


\section{Clinton and Enlargement}

There is no doubt that enlargement happened because the United States decided so, as in the aftermath of the Cold War on the one side the European nations were focused on reducing their military apparatus and divert defence resources elsewhere (see for example Waltz, 2000a), whereas on the other they were concerned that extending the NATO umbrella to former Warsaw Pact nations would antagonise Russia and risk to jeopardise its reform efforts (see for example Eyal, 1997; Hendrickson, 1999; Aggarwal, 2001; MccGwire, 2008 or Walt, 2019). Therefore, there was clearly no appetite in Europe to take on board additional members. Only Germany, because of its geographical position, had shown an early interest in expanding NATO's borders eastwards in order to create a buffer between its eastern borders and a possibly resurgent Russia (see for example Bee, 2001 or Asmus, Kugler, \& Larrabee, 1993).

But what are the reasons that pushed President Clinton to embrace such policy? An academic summarised Clinton's expansion decision as follows:

NATO expansion cannot be said to be part of any grander foreign policy design. Insiders tell us that the idea came to Clinton and his advisors for all the wrong (that is, nonstrategic) reasons: celebrity appeals by Vaclav Havel and Lech Walesa; the personal ambitions of advocates within the administration; lobbying by US arms manufacturers (who just happen to be big campaign contributors) and ethnic East Europeans in the United States (who just might vote); the desire to rob Republicans, who endorsed NATO enlargement in the "contract with America", of a campaign issue; polling results, which showed that foreign policy successes (real or contrived) would improve the president's reelection prospects; and the seductive allure of historical legacy that leads presidents to conflate statecraft and grandstanding (Foster, 1998).

Whereas such statement may sound partisan, it contains most of the elements that led President Clinton to opt for enlargement [see for example 144 Cong. Rec. (Statement by Mr. Moynihan), 1998]. Goldgeier (1999) argues that "finding evidence of the influence of domestic policy on the Clinton administration's decision to enlarge NATO is not easy, particularly since the foreign policy officials take such great pains to insist that domestic policy had no influence" (p. 166). However, there is an enormous body of evidence that establishes a strong relationship between Clinton's 1996 presidential election's campaign and NATO enlargement and that demonstrates that "the president was using a military alliance to fulfill a diplomatic and political agenda" (Goldgeier, 1999, p. 155).

This article defends and substantiates such proposition, demonstrating that President Clinton supported the expansion policy mainly for electoral reasons, and more in detail that:

- There was no political gain in supporting a different policy, on the contrary the only political cost would be paid by voting no.

- President Clinton needed the support of various interest groups to ensure re-election. 
- President Clinton needed to show US leadership in foreign policy to ensure re-election, especially after the Bosnian failures.

- The achievement of such objective was facilitated by the lack of public interest in the issue, the lack of a real public debate and the absence of organised domestic political constituency that opposed expansion.

\subsection{Democrats vs. Republicans: Strange Bedfellows}

In 2001 Rauchhaus made the following observation:

When compared to other democracies, the differences that exist between American political parties are rather small... NATO enlargement nicely illustrates this point. While President Clinton and some key Democrats were calling for NATO enlargement, the Republicans had included it in their Contract with America (p. 184).

The reasons for such support were of course different and based on different calculations of national interest, and even within the democratic party those favouring enlargement were supporting it for very different reasons, from the idea of consolidating democracy in the former communist countries, to the more conservative purpose to consolidate the gains of the Cold War and keep Russia permanently out of Europe.

What is clear is that there was no other choice for President Clinton than supporting a policy of NATO enlargement. Had he decided against NATO enlargement, "he would have alienated... important constituencies, driving them instead into the Republican camp, which would have gained a further issue to capitalize on in both the congressional November 1994 elections as well as the presidential campaign in 1996" (Chaya, 2006, p. 161).

Pressure internal to the Democratic Party was also high as it can be derived, for example, from a 1997 New York Times article, where it was reported that a Polish-American Democrat Senator from Baltimore, Barbara Mikulski, "reportedly told a State Department official that her parents had turned Franklin D. Roosevelt's portrait to the wall after Yalta and said she did not want to have to do the same thing with Mr. Clinton's picture" (Apple, 1997).

Evidence of the importance of NATO enlargement in the US electoral campaign also emerges from the debate taking place outside of the US. Given the special role of Germany in the enlargement discussions, Chancellor Kohl in 1996 urged both parties not to misuse NATO expansion for domestic agendas, in particular the Presidential election campaign in America. As Chaya (2006) reports, "Kohl's warning not to misuse the subject of NATO enlargement for election purposes was also a hidden message to US Republicans, who in the hope for securing US-Polish votes were at the same time wounding the Russian pride" (p. 183). 
It is therefore evident that in the 1996 elections President Clinton could not risk losing the ethnic votes ${ }^{[4]}$ to the Republican Party by choosing a different policy that would have irritated such constituencies, especially at a time when Republicans felt that they and not Bill Clinton were the engine driving enlargement, and were promoting NATO expansion as part of their effort to distinguish their position from that of the Clinton's administration. Therefore, "with the Republican Party supporting enlargement and voters of central European extraction concentrated in important swing states such as Michigan, Ohio and Pennsylvania, Clinton faced potential political incentives to get behind NATO expansion" (Kupchan, 2001, p. 131).

Of utmost importance within the electoral campaign was also the Russia theme. The policy towards Russia was indeed the most important theme underpinning the whole electoral campaign, as President Clinton needed to strike a delicate balancing act between maintaining what was defined by Strobe Talbott the 'Russia First' concept - that is a policy aimed at avoiding any actions that could undermine stability in Russia - and at the same time not to be seen as hostage to Moscow, especially in the eyes of the Republicans and of the most conservative russophobes within his party. At the end of the day, "any electoral benefits would come from those favoring enlargement; there is no American constituency that votes based on a concern about a good relationship with the Russians" (Goldgeier, 1999, p. 107).

As Rauchhaus (2001) notes, and in line with rational theory ${ }^{[5]}$, political calculus would have led any senator to vote for enlargement anyway. Even though voting for expansion would not bring any major advantage, voting against it would have had clear political costs, as it would have alienated various constituents and interests group. Conversely, voting for enlargement would have just alienated some academics and a handful of foreing policy experts. In summary:

Whereas a vote for enlargement could be based on short-term political calculations, a vote against enlargement would require a more abstract and subjective consideration of how enlargement might affect national security in the long run. At a time when America has domestic prosperity and faces few challenges abroad, this asks a lot from politicians (Rauchhaus, 2001, p. 190).

Therefore, the only logical policy option available to the Democrats and to President Clinton to enhance chances for re-election was to embrace enlargement, and in the electoral context both "Congressional and Presidential candidates perceived political gains on this issue and brought it to the people during their campaigns" (Hendrickson, 1999, p. 91).

4. By ethnic voters it is intended American voters having Eastern European origin, in particular Poles, but also Hungarians, Czechs and Slovakians.

5. According to Rational choice theory "actors are assumed to have preferences over the various possible outcomes in any situation and so can rank them in terms of their desirability. They then choose whatever strategy or course of action makes the better outcome most likely" (Kydd, 2008, p. 429). 


\subsection{Lobbying in Action}

It remains unknown when President Clinton actually decided for enlargement ${ }^{[6]}$, but it is clear that this decision came to maturity with the approach of the electoral campaign. Once defined that there was no rational option other than following a NATO enlargement policy, the Clinton administration had the need to respond to the demands of key stakeholders. Literature identifies at least two groups of stakeholders that pressed for enlargement and from whom an electoral advantage would be gained, and namely:

- Voters with origins in Central and Eastern European (CEE) countries;

- The Arms Industry.

Let's analyse if such claims are fundamented.

\subsubsection{The Ethnic Vote}

Was there anything such a CEE ethnic vote? The Clinton administration always dismissed such claim arguing the non-existence of such a voting group. Nonetheless, as already suggested many sources confirm that the 'ethnic vote' played a fundamental role in the decision and that there was an important lobbying and domestic pressure from organised group of CEE voters such as the Polish American Congress among others. For example Chaya (2006) remembers that Zbigniew Brzezinski made sure that this latter Congress "would organize a massive letter-writing campaign to the White House calling for Poland's admission to NATO” (p. 146). Therefore, President Clinton was anything but indifferent to the electoral advantage he would derive by attracting such votes in key states with a long track-record of swinging vote, in particular when considering that the Republican Party "insisted that Clinton was dragging his heels on NATO enlargement" (Bee, 2001, p. 152) in order to captivate themselves the same constituencies.

In this context, McGwire (2008) remembers that "the ethnic vote is very influential in Presidential elections because most of the (roughly) 20 million Americans of Central European origin are concentrated in fourteen key states, which have 194 Presidential electors, a third of the total" (p. 1285). Similarly, Goldgeier (1999) reported about a letter sent by the president of the Polish American Congress to President Clinton asking him "to dispel the growing perception of 19 million Americans with roots in Central and Eastern Europe, including 10 million Polish Americans, that the next Clinton Administration will continue a policy of deferring decisions on NATO enlargement” (Goldgeier, 1999, p. 100). Another source indicated that:

6. A first hint of an upcoming conversion to the NATO enlargement policy can be found in a speech given in Prague in 1994, where President Clinton stated that "while the Partnership is not NATO membership, neither is it a permanent holding room. It changes the entire NATO dialog so that now the question is no longer whether NATO will take on new members but when and how" ("Administration of William J. Clinton, 1994. The President's News Conference With Visegrad Leaders in Prague.”, 1994, p. 40). 
Estimates place the total number of Americans with Eastern European roots at some 20 million, or about 9 percent of the total US population. In the country's highly-competitive election process, where races are often decided by a few percentage points, that is enough to capture the attention of political strategists. But because of the way US presidential elections are decided, their concentration in 10 large states makes them an even more significant political force (Holland, 1999).

In a similar vein, Joseph Biden stated that "the expansion of NATO has great political appeal here in this country [United States] because of the various ethnic American groups" (as cited in Solomon, 1998, p. 124); whereas Waltz reported that “to tout NATO's eastward march, President Clinton gave major speeches in Milwaukee, Cleveland and Detroit, cities with significant eastern European voters" (Waltz, 2000a, p. 22). Similar claims were made by Bee (2001) who reminded that "President Clinton chose... large mid-western cities with significant populations of eastern European immigrants - Cleveland in 1995 and Detroit in 1996" (p. 152) to deliver major speeches in favour of NATO enlargement. Rauchhaus (2001) also defends that:

Clinton and his staff hoped that the [enlargement] policy would allow the President to appeal directly to ethnic eastern European voters [and] announced his support for the policy during campaign stops in key states with large Polish and Czech constituencies, such as Illinois and Michigan in the mid-west and Pennsylvania and New York in the north east (pp. 181-182)

The strength of the Polish-American vote, as well as that of other Americans of Central and East European origin is also one of the main reasons explaining enlargement given by Harries (1997), and finally Aggarwal (2001) stressed that pressure of ethnic groups enmeshed the electoral logic with the future of NATO.

When looking at the potential number of voters with CEE origins, different sources provide contradicting numbers. For example the US census by ancestry in the year 1990 showed 6.5 million people with Polish descendency, about 2.2 million Czechoslovakian and 1 million Hungarian ("Selected Characteristics by Ancestry Group," 1998), whereas in the year 2000 US census by ancestry showed about 6.3 million Polish descendants, 1.5 million between Czech, Bohemian and Slovak, and about 1 million Hungarian ("First, Second, and Total Responses to the Ancestry Question by Detailed Ancestry Code: 2000," 2000). Although it is difficult to reconcile these figures, voters with CEE origins make a significant share of the total voting population in the US, particularly in key states. There is, however, no evidence that such electorate would vote in a compact way as a group.

In summary, there is no clear evidence that by gaining the vote of Americans with Polish, Czech, Hungarian and other CEE roots President Clinton would have derived a clear electoral advantage. There is, however, clear evidence that there was a reasoned political calculum behind the decision to enlarge NATO as, by doing so, there was the expectation that an electoral advantage would be derived. As well observed by Rauchhaus (2001), "although this domestic group did not drive the pol- 
icy, they certainly did raise the immediate political costs for opposing it" (p. 191), and Goldgeier (1999) remembers that the 'when' of enlargement had to be answered before the American presidential election in November 1996 "since otherwise Bill Clinton would get no political benefits from a policy he had been promoting for two years" (p. 77).

\subsubsection{The Arms Industry}

The importance of the lobbying of the arms industry on the enlargement process is twofold, as not only it exercised direct pressure on the Clinton administration via the US Committee to Enlarge NATO, headed by Lockheed Martin Vice President Bruce Jackson, but it also indirectly lobbyed the Polish American community to further pressure the Clinton administration. Evidence of such lobbying is found in the existing literature.

Apart from the cited example of Waltz (2000b) who, in arguing that "votes and dollars are the lifeblood of American politics" (p. 30), made it clear that the American arms industry saw in the new Nations a market in which to expand, many others highlighted the role played by the arms industry in pushing for enlargement. Joel Johnson, the then vice President for International Affairs at Aerospace Industry Association, argued that "the stakes are high. Whoever get in first will have a lock for the next quarter-century" and noting the possible 10 Billion Dollars market for fighter jets added that "there's transport aircraft, utility helicopters, attack helicopters, communications and avionics. Add them together and we're talking real money" (Gerth \& Weiner, 1997). Goldgeier (1999) also remembers how inside industry and US government there was clear consensus that enlargement would be good for business, and Hendrickson (1999) observes that defense industries "had strong incentives for expansion because of the millions of dollars that would be required to improve the new members' military capabilities, and because US defence manufacturers have also faced shrinking domestic markets and additional cutbacks in defence spending" (p. 93).

Similarly, Kupchan (2001) recalls that "not surprisingly, America's defence industry, eyeing a new market, has been a major supporter of NATO enlargement. It is no coincidence that an executive from Lockheed Martin served as the head of the US Committee to expand NATO_-an influential group that helped garner political support for enlargement” (p. 133). By the same token, Rauchhaus (2001) observes that "in the two years leading up to the Madrid summit, the six largest military contractors in the US spent over \$51 million lobbying the US government. NATO enlargement was one of the issues on their agenda" (p. 181), whereas Seelye (1998) pointed out that "American arms manufacturers, who stand to gain billions of dollars in sales of weapons, communication systems and other military equipment if the Senate approves NATO expansion, have made enormous investments in lobbyists and campaign contributions to promote their cause in Washington". 
Defence contractors also helped organise and mobilise other pressure groups such as the Polish and Czech constituencies. For example, Rauchhaus (2001) reminds that "the arms industry... was eager to fund these groups and encourage them to lobby the Clinton administration and Congress for the specific purpose of NATO enlargement" (p. 182) and Seelye (1998) reports that:

The chief vehicle of support for NATO expansion is a group called the US Committee to Expand NATO, which is backed by the arms industry. The committee president is Bruce L. Jackson, who is also director of strategic planning for Lockheed. Corporate sponsors are also supporting ethnic groups that have championed NATO membership for their native countries.

There is, therefore, sufficient evidence that the arms industry lobbyed heavily to push for NATO enlargement, to the extent that Senator Harkin, during a hearing before the Committee on Appropriation of the US Senate stated that "my fear is that NATO expansion will not be a Marshall plan to bring stability and democracy to the newly freed European nations but, rather, a Marshall plan for defense contractors who are chomping at the bit to sell weapons and make profits" (North Atlantic Treaty Organization [NATO] Enlargement Costs, 1998). In summary, one can conclude that:

Narrow electoral concerns triumphed over the national interest. Voting for enlargement kept happy Americans of central European extraction, the defence industry, and conservative Russophobes. In contrast, voting against enlargement may have been the right thing to do, but it had no political payoffs. Indeed, because the Democratic and Republican leadership were both pro-enlargement, party discipline discouraged senators from straying from the fold (Kupchan, 2001, p. 134).

\subsection{Clinton's Foreign Policy}

As suggested, when taking office Clinton's interest in foreign policy was scarce as his focus and energies were devoted to domestic, rather than foreign, policy issues. As a matter of fact, "in the early days of the Clinton administration, Secretary of State Warren Christopher, Secretary of Defense Les Aspin, and Ambassador-at-Large Strobe Talbott were all opposed to [NATO enlargement]" (Harries, 1997). The same President Clinton seemed everything but interested in focusing on foreign policy initiatives, as he had based his presidential campaign on the resolution of those problems that were haunting the domestic economy. As well put by Chaya (2006), "Clinton regarded foreign policy as a distraction from his domestic program, preferring to delegate its formulation to others whenever possible [and] had no regularly scheduled meetings with his foreign policy team" (p. 106).

Therefore, and at least initially, "for an administration determined to concentrate its efforts on domestic affairs and unwilling to commit the United States to the use of force in international affairs - the subject of NATO's eastern enlargement was not high on the policy agenda" (Chaya, 2006, p. 107). The same President Clinton 
corroborated this view at an exchange with reporters on the occasion of the visit of The Netherland's Prime Minister in 1994:

I'm not against expanding NATO. I just think that if you look at the consensus of the NATO members at this time, there's not a consensus to expand NATO at this time and we don't want to give the impression that we're creating another dividing line in Europe after we've worked for decades to get rid of the one that existed before (Administration of William J. Clinton, 1994. Exchange With Reporters Prior to Discussions With Prime Minister Ruud Lubbers of The Netherlands., 1994, p. 6).

Such position was well suited to an era when there was little to gain in foreign policy and much to lose, and certainly not at all at odds within the context of an international environment characterised by the unavoidable unilateralism resulting from US's consolidation of the Cold War victory. For example, Walt (2000) in recognising Clinton's sensitivity for the vox populi, remembers that:

US preponderance and the state of public opinion are inextricably linked. Americans are not interested in foreign policy because they recognize how favourable the current situation is. So they elected a president who promised to spend less time on the phone with foreign leaders and more time on domestic issues, and they elected a Congress whose disdain for foreign affairs is almost gleeful (p. 65).

However, disengagement from foreign policy and the consequent foreign policy blunts he was able to align in the first years of his mandate (the lack of a clear position on NATO enlargement being just one of them), made sure that Clinton became very quickly under attack. Even more paradoxically, most of such failures were in the human rights field, where the rhetorical commitment of the Clinton administration was very high.

To begin with, immediately after the election Clinton found himself in a number of embarrassing retreats, in particular in what regarded human rights abuses in China and the Haiti crisis of 1993 (De Parle, 1995). In the same October 1993, the slaughtering of American soldiers in Somalia eventually led Clinton to withdraw all US Forces in March 1994, creating the impression of a President ill-prepared for foreign affairs. In Walt's (2000) words the mistakes made in Somalia also paved the way for the subsequent, even more tragic failure in Rwanda, where in April 1994 in Rwanda a government-sponsored genocide led to the killing of some 800,000 people of Tutsi ethnic group. Again, Clinton was criticised for not acting quickly and decisively to stop the violent deaths of Rwandans.

During the Bosnia crisis, the Clinton administration was unable to develop a clear policy to solve the conflict, and the President for about two years just maintained a low profile, keeping US involvement to the minimum. As Walt (2000) remembers, in Bosnia "the United States was slow to respond to widespread human rights abuses and was visibly reluctant to place its forces in harm's way” (p. 76). Such 
hesitant position hit back the Clinton administration like a boomerang, to the extent that the Bosnian crisis quickly "overshadowed every other foreign policy issues... making it appear as though the United States was doing very little to alleviate the plight of the Bosnian Muslims" (Chaya, 2006, p. 161).

The lack of a clear strategy and generically the inadequacy of Clinton's foreign policy posture were of course magnified by the critiques received from his detractors. For example, DeParle in 1995, in highlighting how Clinton's foreign policy was in constant assault for lacking a central theme, commented that:

The Administration's foreign policy is derided almost everywhere for being ad hoc, episodic, unsteady, easily reversed. Kissinger says, "Almost everywhere the Administration gets engaged, it recoils before the consequences." Leslie Gelb, president of the Council on Foreign Relations, says Clinton "does not have strong convictions about foreign policy and doesn't spend much time on these issues." Robert Zoellick, an Under Secretary of State in the Bush Administration, says, "The attitude around the world about the constancy, credibility and commitment of our policies has slipped farther than at any time I can remember" (p. 6).

Looking at the NATO enlargement issue, Clinton had come under increasing attack from the Republicans who, inter alia, were accusing him of "selling out NATO's credibility only to appease Russia” (Chaya, 2006, p. 228), whereas Brzezinski (1995) criticised the President for projecting "neither a strategic vision nor a clear sense of direction on a matter of such salience to Europe's future as enlarging NATO” (p. 27), and blamed him for the disgraceful indecisiveness of his policies, which caused in his view the creation of divisive coalitions within NATO. Others, in recognising that Clinton's "more telling weakness in the realm of statecraft has been his failure to... articulate a coherent sense of purpose and direction for the country" (Foster, 1998) stressed as a case in point NATO expansion, a decision taken "without a formal policy review, without a structured evaluation of competing viewpoints, without political debate and over the initial objections of senior military officers" (Apple, 1997).

Starting as a Wilsonian idealist Clinton, under the pressure caused by his foreign policy failures, had to eventually embrace realpolitik: in need to show leadership and "demonstrate that a Democratic president could conduct foreign and defense policy effectively" (Goldgeier, 1999, p. 77), he was compelled to find "an issue that would allow him to demonstrate US leadership without taking any serious foreign policy risk" (Chaya, 2006, p. 161), and the expansion of the Atlantic Alliance would fit such purpose for the reasons so far exposed.

Embracing NATO enlargement would have an enormous political return and, as in the case of the ethnic vote and the arms industry lobbying, Clinton took this clearly into account. For example, Waltz (2000a) observes that America's championing of NATO expansion is also explained by the Clinton's failures in Bosnia: "With the administration's Bosnian policy in trouble, Clinton needed to show himself to be an effective leader in foreign policy" (p. 30). Such vision is also reinforced by 
Goldgeier (1998) who reminds that "Clinton needed to demonstrate US leadership. His administration's foreign policy in Bosnia was failing miserably, and this failure overshadowed every other foreign policy issue at that time" (pp. 94-95).

The same Waltz (2000b) also remembers that in Bosnia "the United States failed to respond until Senator Robert Dole moved to make Bosnia's peril an issue in the forthcoming presidential elections" (p. 24), whereas Rauchhaus (2001) notes that:

The administration floundering policy in the Balkans and NATO's inability to stop the bloodshed also seems to have created the sense that something had to be done to show that the administration was serious about stabilizing Europe. This need was made all the greater by the continued Republican attacks in the months leading up to the elections (p. 186).

In summary, at least initially Clinton's track record in foreign policy was certainly poor and something had to be done to maintain credibility and do not compromise the chances of re-election. The strategic choice made, pushing for NATO enlargement, was probably the safest from a political standpoint since, as observed, there was little to lose and a lot to gain in the short-term. However, most pressing strategic problems with long-term impact were given lower priority, such as the US-Russia relations that, as Walt (2000) highlights, deteriorated significantly during Clinton's tenure:

Because the United States has been so strong and Russia so weak, Clinton has been able to ignore Russian sensitivities whenever doing so brought immediate political benefits. NATO expansion shored up the alliance in Europe and appealed to ethnic voters back home, and Clinton's commitment to missile defense proved that Democrats were not lax on defense. Because Russia could do little to resist either of these initiatives, short-term political calculations won out over long-term strategies (p. 71).

\subsection{NATO Enlargement: So What?}

In a context of unchallenged supremacy as the only superpower, and in a country of little track-record of interest in foreign policy, one should question up to what extent NATO enlargement was an issue of interest to the general public and to politicians alike. My research shows that public attention was nearly non-existent; that politicians had little or no interest in the issue, other than for parochial returns, and that there was no real public debate around the necessity of expanding NATO. Only academics were opposed to it, but no organised domestic political constituency emerged to oppose expansion with the exception of few political pundits ${ }^{[7]}$. In such a context, it is obvious that for President Clinton it was much easier to pursue his objectives, as an uninterested public would in turn give much more flexibility to members of Con-

7. An example of such opposition can be found in an open letter sent to President Clinton on 26 June 1997 by a group of 50 prominent foreign policy experts that included former senators, retired military officers, diplomats and academicians (published in Resor, 1997). 
gress to use their vote in the way that best fit their agendas. Fully aware of this opportunity, among other initiatives President Clinton "hired an advisor whose sole task has been to get the 67 Senate votes needed for [enlargement] ratification" (Marshall, 1998). I will now analyse these claims with the aim to demonstrate that Clinton's use of enlargement as a tool to increase his chances for re-election was favoured by the fact that NATO expansion was an issue of no interest for the Americans at large.

\subsubsection{The General Public}

In a recent article on the American public's indifference to foreign affairs, G. Friedman (2014) notes:

There is a feeling that Americans ought to be more involved in public affairs... The sense that private life matters more than public is intense, and that means that Americans are concerned with things that are deemed frivolous by foreigners, academics and others who make their living in public and foreign policy. They care about some things, but are not prepared to care about all things.

Certainly, at time of the NATO enlargement debate, the American people did not care at all, as demonstrated by triangulating the various data collected from existing literature (newspapers, books), existing surveys and interviews. An opinion survey by the Pew Research Center released on January 24, 1997, found that the US public was uninterested and equivocal about the question of expanding the alliance, with only $5 \%$ of the population following the enlargement debate very closely (Pew Research Center, 1997b). The survey also found that only $45 \%$ of respondents provided a positive answer to the question whether NATO should expand or not and that the overwhelming majority of respondents (85\%) thought that President Clinton should focus on domestic policy as opposed to foreign policy (7\% only).

Another Pew Research Center's poll dated October 7, 1997 found out that people and opinion leaders in general favoured NATO enlargement; however, "most enthusiastic for expansion are Union, Business and Religious leaders. Least welcoming (although still a majority) are the Foreign Affairs and Security groups, whose members are ostensibly the most knowledgeable about diplomatic and defense issues" (Pew Research Center, 1997a). The same report also highlighted "the scant knowledge among the public about which countries have been invited to join. Specifically, only $10 \%$ of the public was able to identify even one of the potential new members".

In a New York Times article, Apple (1997) observed:

The public, whose interest in foreign policy has waned since the crumbling of the Berlin wall and of Communist governments almost everywhere, has paid little attention-even though the expansion of NATO will commit the United States to fight if need be for Prague and Budapest precisely as it is now committed to defending cities like Berlin and Paris. 
Similarly, Marshall (1998) indicated that the enlargement issue "although enormously important for the United States, has barely raised the average American's eyebrow" and clarified that "for the general public, NATO expansion remains a yawn. Despite the vigorous debate among policymakers and the enormous stakes, the only questions coming from the street seems to be "Does it matter?" and "Who cares?"

Analogous considerations could also be found in Kupchan (2001), who observed that without the Soviet Union around, foreign policy does not captivate the audience, or Rauchhaus (2001), who also recollects that the public reacted to the proposal of NATO enlargement "with a collective yawn" (p. 188).

In summary, there is large evidence that the lack of public interest on the issue of NATO enlargement played to President Clinton's favour. As Goldgeier (1999) observes "member of Congress often have tremendous freedom to act in foreign policy because most voters are not paying attention to these issues... What the administration had to do was make it easy for senators to vote yes" (p. 110).

\subsubsection{The Congress}

It has already been suggested that political calculus led senators to vote yes, as there was no payoff to vote against enlargement. This is no surprise since, as commented, the average American cared little about the issue. One of the more caustic observations was made by the then Canadian Prime Minister Jean Chretien who speaking with the then Belgian Prime Minister on 10 July 1997 in the margins of a NATO meeting and thinking that the microphone was switched off, bluntly commented NATO enlargement as follows:

All this for short-term political reasons, to win elections... In fact, they are selling their votes, they are selling their votes. 'You want me to vote for NATO? Don't forget the bridge in my district'... It's incredible. In your country or in mine, all the politicians would be in prison (Agence France-Presse, 1997).

Indeed, and again looking at the context in which the NATO enlargement was being pursued, at a time when the US enjoyed uncontested global primacy and with both Republican and Democrats backing the policy, senators could afford to act irresponsibly, with a "negligence born of complacency" (Kupchan, 2001, p. 135). Lack of interest also played a fundamental role, as "the Senate approved the policy after little debate mainly because most senators simply did not care about the issue" (Kupchan, 2001, p. 128).

Literature also demonstrates that the general lack of interest in the subject for both the majority of the Congress and people alike was reflected in the little consultation and public debate that accompanied the approval of the policy, but it also clarifies that the lack of consultation and visible public debate of such an important foreign policy initiative was first and foremost a deliberate choice of the Clinton administration. Sorensen, (1995) argues that "it is hard to imagine a more provocative decision taken with less consultation and consideration for the consequences", and 
Goldgeier (1999) observes that "throughout the ratification process the administration had made little effort after 1994 to take its case to Congress and to the public" (p. 60), adding that "the lack of administration consultation with congressional enlargement supporters until 1997 is disturbing because it meant that there was no real public debate held until after membership invitations had been issued" (p. 164). Also Rauchhaus (2001) remembers that "to say that there was even a real debate may indeed be an overstatement. Aside from Foreign Affairs and a few leading newspapers such the Washington Post and the New York Times, the policy never captured much attention" (p. 188). In substance, by the time the debate was actually started, it was already too late for senators to vote against had they so wished.

\subsubsection{Organised Campaigners vs. Disorganised Opponents}

As demonstrated, in the political realm there were a large number of factors that eventually led to the vote in favour of the enlargement policy. NATO expansion was supported by well mobilized and organized interest groups, whereas opposition forces were weak and public in general uninformed. The efforts of journalists and academics writing in newspapers, academic journals and magazines, all contrary to NATO expansion, paled when compared to the organised campaign of such groups.

As Hendrickson (1999) remembers, ethnic European Nongovernmental Organizations (NGOs) with large constituencies throughout the United States were very active and included groups such as the Polish American Congress (PAC), with representations in 32 states across the United States. PAC's activities included, inter alia, the co-ordination of grassroots efforts in mobilizing its district membership and helped bring together a coalition of nationwide ethnic groups called the Central and East European Coalition (CEES), which consisted of 19 NGOs of 12 different nationalities. These groups consistently developed strategies to promote enlargement with initiatives including for example the targeting of individual senators by means of letters, and all converged into the NATO Ratification working Group that was also joined by other associations such as the Veterans of Foreign Wars, the American Legion and others.

Also very important were the organised efforts of the administration's NATO Enlargement Ratification Office, the NATO Observer Group and the US Committee to Expand NATO, and fundamental was the strategy pursued by the Clinton administration once the decision to enlarge was taken, as a major public relation campaign was launched to sell enlargement. As Goldgeier (1999) recalls:

For the year before the Senate debate in March 1998, Jeremy Rosner and Cameron Munter had travelled anywhere and everywhere to pick up support. They visited thirty states and targeted the editorial boards of the thirty papers with the highest circulation... In January 1998 the NATO enlargement ratification office laid out a week-by-week strategy to culminate in the expected Senate vote on March 20: who would go where, which foreign policy principals would speak when, how the president would play his part in the process (p. 134). 
One topic of interest in the context of the campaign was certainly the cost that NATO expansion eastwards would entail, firstly for the US and secondly for the other NATO nations and the new entrants. Indeed, one of the issues that would have most likely created hurdles to the expansion campaign was the potential opposition from senators in case financing enlargement would subtract from other more important priorities close to their constituencies. Campaigners were therefore often silent or minimised the overall cost of enlargement and estimates were often inaccurate or strangely shrank. For example, different cost estimates were developed by the Department of Defence, RAND Corporation and the Congressional Budget Office, spanning from 27 billion US Dollars (DOD) up to 125 billion US Dollars (CBO). Nonetheless a report from the US General Accounting Office (1997) argued that cost estimates developed to the date were notional and that pricing of cost elements could not be verified, and concluded that "the uncertainties associated with the military implications of NATO enlargement and DOD's estimating procedures resulted in cost estimates that were notional and that could differ substantially from actual enlargement costs" (p. 14).

The truth is that "no systematic effort to assess costs was undertaken when the administration first began to consider enlargement" (Goldgeier, 1999, p. 131) and estimates did not receive much scrutiny in the Senate. Furthermore, once estimates started circulating, all critics complained that such estimates were deliberately low, arguing that prospective member states should spend money in their economies as opposed to joining a military alliance.

In short, nearly all domestic political factors favoured enlargement. NATO expansion was generally not seen as controversial by the American public and well-organised constituencies supported enlargement... In sum, domestic political conditions provided strong incentives for the United States to work vigorously for alliance expansion (Hendrikson, 1999, pp. 93-94).

\section{Conclusions}

The enlargement of NATO has triggered a lot of interest in the academic literature and many reasons have been brought forward that can possibly explain the rationale for the expansion of the Alliance, to include the securitisation and stabilisation of Europe, the democratisation of the countries formerly under the Soviet yoke or the enhancement of the Alliance's effectiveness and cohesion. Although the validity of such propositions was not discarded, this article focused on the reasons why the Clinton administration decided to embrace the NATO expansion policy, demonstrating that the then President of the US opted for enlargement for domestic political returns, that is he espoused this policy to enhance his chances of re-election.

Although other studies came to similar conclusions, no existing study could be found that addressed this issue in a comprehensive manner. This article has tried to fill this gap by providing a longitudinal study that exhaustively addresses the phenomenon at large. Through an exhaustive analysis of primary and secondary 
sources, the article offers unquestionable evidence that indeed President Clinton used enlargement to harvest political advantage. In particular, it has been proved that there would be no political gain in supporting a different policy, on the contrary only political costs; that President Clinton needed the support of various interest groups in order to ensure re-election, to include the votes of the Polish-American, mostly located in key states, and the support of the arms industry, both groups pushing for enlargement. Finally, President Clinton needed to demonstrate leadership in foreign policy to enhance his chances for re-election after a long track-record of failures. It has also been demonstrated that the achievement of such objective was facilitated by the lack of public interest in the issue and by the absence of an organised constituency that opposed expansion.

Data de receção:31/01/2019

Data de aprovação:07/05/2019

\section{References}

144 Cong. Rec. (Statement by Mr. Moynihan). (1998). Retrieved May 14, 2019, from <https:// www.gpo.gov/fdsys/pkg/CREC-1998-03-03/html/CREC-1998-03-03-pt1-PgS1283-3. htm>.

Administration of William J. Clinton, 1994. Exchange With Reporters Prior to Discussions With Prime Minister Ruud Lubbers of The Netherlands. (1994). Retrieved May 14, 2019, from <https://www.govinfo.gov/content/pkg/PPP-1994-book1/pdf/PPP-1994book1-doc-pg5.pdf>.

Administration of William J. Clinton, 1994. The President's News Conference With Visegrad Leaders in Prague. (1994). Retrieved from <https:/www.govinfo.gov/content/pkg/ PPP-1994-book1/pdf/PPP-1994-book1-doc-pg39-2.pdf $>$.

Agence France-Presse. (1997). Oops! A Blunt Canadian on NATO. Retrieved January 29, 2016, from <http://www.nytimes.com/1997/07/11/world/oops-a-blunt-canadian-on-nato. html?mcubz=0>.

Aggarwal, V. K. (2001). Analysing NATO Expansion: An Institutional Bargaining Approach. In R. W. Rauchhaus (Ed.), Explaining NATO Enlargement (pp. 63-82). Portland, OR: Frank Cass Publishers.

Apple, R. W. (1997). Road to Approval Is Rocky, And the Gamble Is Perilous. The New York Times. Retrieved from <http://www.nytimes.com/1997/05/15/world/road-to-approval-is-rocky-and-the-gamble-is-perilous.html>.

Asmus, R. D., Kugler, R. L., \& Larrabee, F. S. (1993). Building a New NATO. Foreign Affairs, 72(4), 28-40.

Bee, R. J. (2001). Boarding the NATO Train: Enlargement and National Interests. In R. W. Rauchhaus (Ed.), Explaining NATO Enlargement (pp. 149-169). Portland, OR: Frank Cass Publishers. 
Brzezinski, Z. (1995). A Plan for Europe: How to Expand NATO. Foreign Affairs, 74(I), 26-42. $<$ https://doi.org/http://dx.doi.org/10.1108/17506200710779521>.

Carrol, E. J. (1997). NATO Expansion Would Be an Epic “Fateful Error." Los Angeles Times. Retrieved from <http://articles.latimes.com/print/1997/jul/07/local/me-10464>.

Carrol, E. J. (1998). On NATO, How Will Russia React? Kennan's Warning. The New York Times.

Chaya, A. (2006). Germany's Civilian Power Diplomacy: NATO Expansion and the Art of Communicative Action. New York, NY: Palgrave Macmillan.

DeParle, J. (1995). The Man Inside Bill Clinton's Foreign Policy. The New York Times. Retrieved from <http://www.nytimes.com/...8/20/magazine/the-man-inside-bill-clinton-s-foreign-policy.html?pagewanted=all\&pagewanted=print $>$.

Dobbins, J. F. (1990). [Memorandum]. U.S. Department of State. Retrieved from https://nsarchive2.gwu.edu//dc.html?doc=4325704-Document-26-U-S-Department-of-State-European

Eyal, J. (1997). NATO’s Enlargement: Anatomy of a Decision. International Affairs, 73(4), 695719.

First, Second, and Total Responses to the Ancestry Question by Detailed Ancestry Code: 2000. (2000). Retrieved May 27, 2017, from <https://www.census.gov/data/tables/2000/dec/ phc-t-43.html>.

Foster, G. D. (1998). Senate Has a Job to Do on NATO Expansion. Los Angeles Times. Retrieved from <http://articles.latimes.com/1998/feb/16/local/me-19765>.

Friedman, G. (2014). The American Public's Indifference to Foreign Affairs. Retrieved August 6, 2017, from <http://www.stratfor.com/weekly/american-publics-indifference-foreign-affairs\#axzz3CwXhdLuX> .

Friedman, T. L. (1998). Foreign Affairs; Madeleine's Folly. The New York Times. Retrieved from $<$ http://www.nytimes.com/1998/02/17/opinion/foreign-affairs-madeleine-s-folly. html>.

Gaddis, J. L. (1998, April 27). The Senate Should Halt NATO Expansion. The New York Times. New York. Retrieved from <http://www.nytimes.com/1998/04/27/opinion/the-senateshould-halt-nato-expansion.html $>$.

Gerth, J., \& Weiner, T. (1997, June 29). Arms Makers See a Bonanza in Selling NATO Expansion. Retrieved June 4, 2017, from <http://www.nytimes.com/1997/06/29/world/ arms-makers-see-bonanza-in-selling-nato-expansion.html>.

Goldgeier, J. M. (1998). NATO Expansion: The Anatomy of a Decision. The Washington Quarterly, 21(1), 83-102.

Goldgeier, J. M. (1999). Not Whether but When. The U.S. Decision to Enlarge NATO. Washington, D.C.: Brookings Institution Press.

Hallams, E., Ratti, L., \& Zyla, B. (2013). Introduction - A New Paradigm for NATO? In E. Hallams, L. Ratti, \& B. Zyla (Eds.), NATO Beyond 9/11 (pp. 1-23). Basingstoke: Palgrave Macmillan.

Harries, O. (1997). The Dangers of Expansive Realism. The National Interest, (Winter 19971998), 1-6. Retrieved from <http://nationalinterest.org/article/the-dangers-of-expansive-realism-551>. 
Hendrickson, R. C. (1999). The Enlargement of NATO: The Theory and Politics of Alliance Expansion. European Security, 8(4), 84-99.

Holbrooke, R. (1995). America, A European Power. Foreign Affairs, 74(2), 38-51.

Holland, L. (1999). United States: The Role Of The Central And Eastern European Vote. Retrieved May 28, 2017, from <https://www.rferl.org/a/1081917.htm>.

Kennan, G. (1998). The Dangers of Expansive Realism. Congressional Record (Vol. 144). Washington, D.C.: The Government Publishing Office. Retrieved from <https://www.gpo. gov/fdsys/pkg/CREC-1998-03-03/html/CREC-1998-03-03-pt1-PgS1283-3.htm>.

Kupchan, C. A. (2001). Origins and Future of NATO Enlargement. In R. W. Rauchhaus (Ed.), Explaining NATO Enlargement (pp. 127-148). Portland, OR: Frank Cass Publishers.

Kydd, A. H. (2008). Methodological Individualism and Rational Choice. In C. Reus-Smit \& D. Snidal (Eds.), The Oxford Handbook of International Relations (pp. 425-443). Oxford: Oxford University Press.

Mandelbaum, M. (1995). Preserving the New Peace: The Case against NATO Expansion. Foreign Affairs, 74(3), 9-13.

Marshall, T. (1998). U.S. Public Acutely Uninterested in Vote on NATO Expansion. Retrieved August 18, 2017, from <http://articles.latimes.com/print/1998/apr/08/news/mn37245>.

MccGwire, M. (2008). NATO Expansion: “A policy error of historic importance.” International Affairs, 84(6), 1281-1301.

North Atlantic Treaty Organization [NATO] Enlargement Costs: Hearings before the Committee on Appropriations, Senate, 105th Congr. 15. (1998). Retrieved from <https://www.gpo. gov/fdsys/pkg/CHRG-105shrg46492/pdf/CHRG-105shrg46492.pdf>.

OSCE. (1994). OSCE Code of Conduct on Politico-Military Aspects of Security. Retrieved from http://www.osce.org/fsc/41355

Pew Research Center. (1997a). Public and Opinion Leaders Favor NATO Enlargement. Retrieved from <http://assets.pewresearch.org/wp-content/uploads/sites/5/legacy-pdf/103.pdf>.

Pew Research Center. (1997b). Public Indifferent about NATO Expansion. Retrieved August 21, 2017, from <http://www.people-press.org/1997/01/24/public-indifferent-about-nato-expansion/>.

Rauchhaus, R. W. (2001). Explaining NATO Enlargement. In R. W. Rauchhaus (Ed.), Explaining NATO Enlargement (pp. 173-194). Portland, OR: Frank Cass Publishers.

Resor, S. (1997). Opposition to NATO Expansion. Retrieved June 26, 2017, from <https:// www.armscontrol.org/act/1997_06-07/natolet>.

Seelye, K. Q. (1998, March 30). Arms Contractors Spend to Promote an Expanded NATO. Retrieved from <http://www.nytimes.com/1998/03/30/world/arms-contractors-spendto-promote-an-expanded-nato.html>.

Selected Characteristics by Ancestry Group. (1998). Retrieved May 28, 2017, from <https:// www.census.gov/data/tables/time-series/dec/cph-series/cph-1/cph-l-149.html>.

Solomon, G. B. (1998). The NATO Enlargement Debate, 1990-1997. Westport, CT: Praeger Publishers.

Sorensen, T. C. (1995). The Star Spangled Shrug. The Washington Post. 
U.S. General Accounting Office. (1997). NATO Enlargement: Cost Estimates Developed to Date Are Notional. Retrieved from <http://www.gao.gov/products/NSIAD-97-209>.

Walt, S. M. (2000). Two Cheers for Clinton's Foreign Policy. Foreign Affairs, 79(2), 63-79.

Walt, S. M. (2019). The End of Hubris. Foreign Affairs, 98(3), 26-35.

Waltz, K. N. (2000a). NATO expansion: A realist 's view. Contemporary Security Policy, 21(2), 23-38.

Waltz, K. N. (2000b). Structural realism after the Cold War. International Security, 25(1), 5-41.

Waltz, K. N. (2001). NATO Expansion: A Realist's View. In R. W. Rauchhaus (Ed.), Explaining NATO Enlargement (pp. 23-38). Portland, OR: Frank Cass Publishers.

Webber, M. (2013). NATO after 9/11: Theoretical Perspectives. In E. Hallams, L. Ratti, \& B. Zyla (Eds.), NATO Beyond 9/11 (pp. 27-53). Basingstoke: Palgrave Macmillan.

\section{Sobre o autor}

LUCA RANISE é doutorado pela Universidade de Lisboa, Instituto Superior de Ciências Sociais e Políticas (ISCSP-ULisboa). Mestre em Administração Pública e Gestão de Empresas pela OU Business School, Milton Keynes, Reino Unido e licenciado pela Universidade IULM de Milão, Itália. Investigador do Centro de Literaturas e Cultura Lusófonas e Europeias (CLEPUL). Áreas de interesse de investigação: alargamento da NATO, a função de democratização da Aliança Atlântica e a sua relevância no século xxi. Tem diversos trabalhos publicados e várias participações em seminários e conferências. É funcionário internacional.

\footnotetext{
About the author

LUCA RANISE holds a PhD in International Relations from the University of Lisbon, Instituto Superior de Ciências Sociais e Políticas (ISCSP-ULisboa), a master's degree in Public Administration and Business Administration from the OU Business School, Milton Keynes, UK and a bachelor's degree from the IULM University of Milan, Italy. He is researcher at the Centro de Literaturas e Cultura Lusófonas e Europeias (CLEPUL). His research interests revolve around NATO enlargement, the democratization function of the Atlantic Alliance and its relevance in the $21^{\text {st }}$ century. He has published several papers and participated in many seminars and conferences. He is an international functionary.
} 